Article

\title{
New Eudesmane-Type Sesquiterpene Glycosides from the Leaves of Aster koraiensis
}

\author{
Ji-Young Kim ${ }^{1,+}$, Young Hye Seo ${ }^{2,+}$, Im-Ho Lee ${ }^{1}$, He Yun Choi ${ }^{1}$, Hak Cheol Kwon ${ }^{3}$, \\ Jung-Hye Choi ${ }^{1}$, Jun Lee ${ }^{2, *}$ and Dae Sik Jang ${ }^{1, *}$ \\ 1 Department of Life and Nanopharmaceutical Sciences, Graduate School, Kyung Hee University, Seoul 02447, \\ Korea; k_christina@khu.ac.kr (J.-Y.K.); dlagh93@naver.com (I.-H.L.); choiheyun@khu.ac.kr (H.Y.C.); \\ jchoi@khu.ac.kr (J.-H.C.) \\ 2 Herbal Medicine Resources Research Center, Korea Institute of Oriental Medicine (KIOM), Naju 58245, \\ Korea; wnsl1118@kiom.re.kr \\ 3 Natural Product Informatics Research Center, Korea Institute of Science and Technology (KIST) Gangneung \\ Institute, Gangneung 25451, Korea; hkwon@kist.re.kr \\ * Correspondence: junlee@kiom.re.kr (J.L.); dsjang@khu.ac.kr (D.S.J.) \\ + These authors contributed equally to this work and joint first authors.
}

Received: 20 November 2020; Accepted: 18 December 2020; Published: 21 December 2020

\begin{abstract}
Four new eudesmane-type sesquiterpenoids, $(1 R, 5 S, 6 R, 7 S, 9 S, 10 S)-1,6,9$-trihydroxy-eudesm3-ene-1,6-di-O- $\beta$-D-glucopyranoside (1), (1R,5S,6S,7R,9S,10S)-1,6,9,11-tetrahydroxy-eudesm-3-ene-1,6di-O- $\beta$-D-glucopyranoside (3), (1R,5S,6R,7S,9S,10R)-9-O-(Z-p-coumaroyl)-1,6,9-trihydroxy-eudesm-3 -ene-6-O- $\beta$-D-glucopyranoside (6), and (1R,5S,6R,7S,9S,10R)-9-O-(E-feruloyl)-1,6,9-trihydroxy-eudesm3-ene-6-O- $\beta$-D-glucopyranoside (7), were isolated from a $95 \% \mathrm{EtOH}$ extract of the leaves of Aster koraiensis by repeated chromatography. Moreover, three sesquiterpenoids $(\mathbf{2}, \mathbf{4}$, and 5$)$ and two caffeoylquinic acids (8 and $\mathbf{9}$ ) having previously known chemical structures were isolated during the isolation procedure. The four new compounds $(\mathbf{1}, \mathbf{3}, \mathbf{6}$, and $\mathbf{7})$ were elucidated by spectroscopic data (1D- and 2D-NMR, MS, and ECD) interpretation and hydrolysis. Moreover, the absolute configurations of $\mathbf{2}, \mathbf{4}$, and $\mathbf{5}$ were determined for the first time in this study. The compounds isolated were tested for their viability on nitric oxide $(\mathrm{NO})$ and prostaglandin $\mathrm{E}_{2}\left(\mathrm{PGE}_{2}\right)$ production on LPS-stimulated RAW 264.7 cells. Among them, only 7 presented weak inhibitory effects on both NO and $\mathrm{PGE}_{2}$ production.
\end{abstract}

Keywords: Aster koraiensis; Compositae; sesquiterpenoids; dicaffeoylquinic acids; nitric oxide; prostaglandin $\mathrm{E}_{2}$; anti-inflammation

\section{Introduction}

Aster koraiensis Nakai (syn. Gymnaster koraiensis (Nakai) Kitamura; Compositae) is an endemic species to Korea that is distributed from Jeju Island to the southern parts of Gangwon-do [1]. The young leaves and stems of $A$. koraiensis have been used in Korean cuisines and also used to ornamental plant for beautiful flowers [1]. It has been used for chronic bronchitis, pneumonia, antitussive, and pertussis in Korean folk medicine [2].

It has been reported that the extracts of $A$. koraiensis have a variety of biological activities including anti-proliferative activity on human and mouse tumor cell lines [3,4]. The extracts also exhibited antioxidant and $\alpha$-glucosidase inhibitory activities [5]. Furthermore, it was reported that $A$. koraiensis protects retinal ganglion cells against oxidative stress in diabetic rats [6]. 3,5-O-Dicaffeoylepiquinic acid isolated from A. koraiensis showed inhibitory activity on AKR1B10 for cancer therapy and on formation of advanced glycation end products (AGEs) to treat diabetic nephropathy $[7,8]$. Similarly, chlorogenic acid 
from A. koraiensis reduced AGE formation and AGE/RAGE binding activity [9]. A polyacetylene, gymnasterkoreayne $B(G K B)$, from this plant induced a variety of detoxification enzymes and exhibited a hepatoprotective effect and cytotoxicity against cancer cells [10]. Besides, gymnasterkoreayne G, which has a similar chain structure to GKB, has activity on the modulation of NFAT transcription factor [11]. Other polyacetylenes from A. koraiensis have acyl CoA: Cholesterol acyltransferase (ACAT) activities in rat liver microsomes [12,13].

Previous chemical studies on $A$. koraiensis have led to the identification of several types of secondary metabolites, such as polyacetylenes [3,10-12,14], sesquiterpenoids [4,15-17], triterpenoids [18], flavonoids [4,16,17], ionones [17], caffeoylquinic acids [16], and benzofurans [16,19]. However, active compounds with anti-inflammatory activities in this plant has been poorly studied. In an ongoing project directed toward the search for bioactive compounds in plants, the leaves of $A$. koraiensis were chosen for phytochemical investigation, since its 95\% EtOH extract was found to inhibit production of prostaglandin $\mathrm{E}_{2}\left(\mathrm{PGE}_{2}\right)$ and lipopolysaccharide (LPS)-induced nitric oxide (NO) in RAW 264.7 macrophages.

Various chromatographic separation led to the isolation and characterization of four new eudesmane-type sesquiterpenoid glycosides $(\mathbf{1}, \mathbf{3}, \mathbf{6}$, and 7) and five known compounds $(\mathbf{2}, \mathbf{4}, \mathbf{5}$, 8, and 9) from the leaves of $A$. koraiensis. The structures of 1-7 were elucidated by interpreting oneand two-dimensional (D) nuclear magnetic resonance (NMR) spectroscopic data analysis, enzymatic and acid hydrolysis, and electronic circular dichroism (ECD) calculation. Two caffeoylquinic acids (8 and 9) were identified by measurement of NMR spectroscopic data and by comparison with published values. The compounds obtained were evaluated for their activities on the production of the pro-inflammatory mediators, $\mathrm{NO}$ and $\mathrm{PGE}_{2}$, in RAW264.7 macrophages. We describe in this paper the isolation of compounds from the leaves of $A$. koraiensis, structure elucidation of the seven sesquiterpenes, and inhibitory activities of the isolates against production of $\mathrm{NO}$ and $\mathrm{PGE}_{2}$.

\section{Results and Discussion}

\subsection{Structure Elucidation of $\mathbf{1 - 7}$}

Four new compounds $(1,3,6$, and 7$)$ and five known compounds $(2,4,5,8$, and 9$)$ were isolated from $95 \% \mathrm{EtOH}$ extract of the leaves of $A$. koraiensis in the present research (Figure 1).

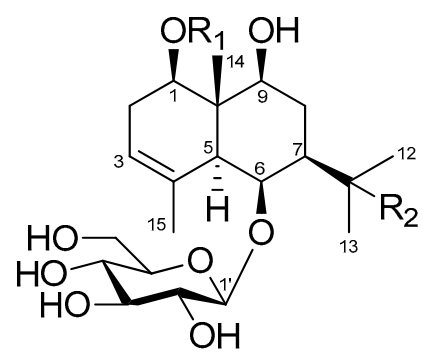

$1 \mathrm{R}_{1}=\mathrm{Glc}, \mathrm{R}_{2}=\mathrm{H}$

$2 \mathrm{R}_{1}=\mathrm{R}_{2}=\mathrm{H}$

$3 \mathrm{R}_{1}=\mathrm{Glc}, \mathrm{R}_{2}=\mathrm{OH}$

$4 \quad \mathrm{R}_{1}=\mathrm{H}, \quad \mathrm{R}_{2}=\mathrm{OH}$<smiles>[R]C1CCC(C)=C2C=C(C(C)C)CC(O)[C@]21[C@@H](C)O</smiles>

1a $\mathrm{R}=\mathrm{Glc}$

1b $\mathrm{R}=\mathrm{H}$<smiles>[R6]O[C@H]1C[C@@](O)(C(=O)O)C[C@H]([R6])[C@H]1[R20]</smiles>

$8 \mathrm{R}_{1}=\mathrm{R}_{3}=$ Caffeoyl, $\mathrm{R}_{2}=\mathrm{H}$

$9 R_{1}=H, R_{2}=R_{3}=$ Caffeoyl

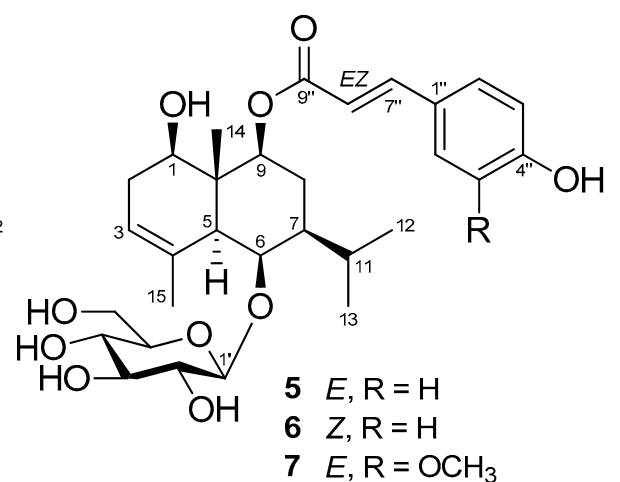<smiles>CC(=O)/C=C/c1ccc(O)c(O)c1</smiles>

Caffeoyl

Figure 1. Chemical structures of 1-9 isolated from the leaves of A. koraiensis. 
Compound $\mathbf{1}$ was isolated as a white powder. The molecular formula of $\mathbf{1}$ was established as $\mathrm{C}_{27} \mathrm{H}_{46} \mathrm{O}_{13}$ by HR-ESI-MS $\left(m / z=601.2938[\mathrm{M}+\mathrm{Na}]^{+}\right.$; calcd for $\left.\mathrm{C}_{27} \mathrm{H}_{46} \mathrm{O}_{13} \mathrm{Na}, 601.2836\right)$ (Figure S1). The infrared absorption spectrum showed absorption bands at 3437, 2917, 1358, and $1010 \mathrm{~cm}^{-1}$, implicating that $\mathbf{1}$ has hydroxyl and olefinic groups. The ${ }^{1} \mathrm{H}-\mathrm{NMR}$ spectroscopic data of $\mathbf{1}$ exhibited two doublet methyl signals at $\delta_{\mathrm{H}} 1.11(3 \mathrm{H}, \mathrm{d}, J=6.0 \mathrm{~Hz})$ and $0.85(3 \mathrm{H}, \mathrm{d}, J=6.5 \mathrm{~Hz})$, two singlet methyl signals at $\delta_{\mathrm{H}} 2.10(3 \mathrm{H}, \mathrm{s})$ and $1.64(3 \mathrm{H}, \mathrm{s})$, two anomeric protons at $\delta_{\mathrm{H}} 4.99(1 \mathrm{H}, \mathrm{d}, J=8.0 \mathrm{~Hz})$ and 4.92 $(1 \mathrm{H}, \mathrm{d}, J=8.0 \mathrm{~Hz})$, and an olefinic proton at $\delta_{\mathrm{H}} 5.30(1 \mathrm{H}, \mathrm{br} \mathrm{s})$ (Table 1, Figure S2). The ${ }^{13} \mathrm{C}-\mathrm{NMR}$ spectrum of 1 indicated four methyl carbons $\left(\delta_{C} 22.0,21.9 \times 2\right.$, and 10.7), two methylene carbons $\left(\delta_{C} 30.3\right.$ and 29.4$)$, three oxygenated methine carbons $\left(\delta_{C} 80.2,78.4\right.$, and 76.6$)$, and four methine carbons $\left(\delta_{C} 120.4,52.3,51.7\right.$, and 29.0$), 12$ carbons $\left(\delta_{C} 104.6,102.1,86.4,78.4,78.1,77.4,76.2,75.4,72.1,71.6\right.$, 63.4, and 62.9) assignable to the glucose moieties including two anomeric carbons and two quaternary carbons $\left(\delta_{\mathrm{C}} 136.7\right.$ and 43.0$)$ (Table 1, Figure S3).

Table 1. ${ }^{1} \mathrm{H}$ and ${ }^{13} \mathrm{C}$ nuclear magnetic resonance (NMR) spectroscopic data of $\mathbf{1}$ and $\mathbf{3}$ ( $\delta$ in ppm, $\mathrm{C}_{5} \mathrm{D}_{5} \mathrm{~N}, 500$, and $125 \mathrm{MHz}$ ).

\begin{tabular}{|c|c|c|c|c|}
\hline \multirow{2}{*}{ Position $^{a}$} & \multicolumn{2}{|l|}{1} & \multicolumn{2}{|l|}{3} \\
\hline & $\delta_{\mathrm{H}}$ Multi $(J$ in $\mathrm{Hz})$ & $\delta_{\mathrm{C}}$ & $\delta_{\mathrm{H}}$ Multi $(J$ in $\mathrm{Hz})$ & $\delta_{\mathrm{C}}$ \\
\hline 1 & $4.18 \mathrm{~d}(9.5)$ & 78.4 & $4.17 \mathrm{~m}$ & 79.4 \\
\hline 2 & $2.06 \mathrm{~m} / 2.25 \mathrm{td}(13.0,11.0)$ & 30.3 & $2.73 \mathrm{q}(12.0) / 2.21 \mathrm{~m}$ & 28.5 \\
\hline 3 & $5.30 \mathrm{br} \mathrm{s}$ & 120.4 & $4.98 \mathrm{br} \mathrm{s}$ & 120.7 \\
\hline 4 & - & 136.7 & - & 136.7 \\
\hline 5 & $1.83 \mathrm{br} \mathrm{s}$ & 52.3 & $1.83 \mathrm{~s}$ & 52.3 \\
\hline 6 & $4.64 \mathrm{~m}$ & 76.6 & $4.66 \mathrm{br} \mathrm{s}$ & 80.2 \\
\hline 7 & $0.99 \mathrm{~m}$ & 51.7 & $1.37 \mathrm{~s}$ & 51.6 \\
\hline 8 & $2.37 \mathrm{~m} / 2.53 \mathrm{~m}$ & 29.4 & $2.48 \mathrm{~m}$ & 27.3 \\
\hline 9 & $4.08 \mathrm{~m}$ & 80.2 & $4.16 \mathrm{~m}$ & 85.0 \\
\hline 10 & - & 43.0 & - & 42.9 \\
\hline 11 & $2.37 \mathrm{~m}$ & 29.0 & - & 72.6 \\
\hline 12 & $0.85 \mathrm{~d}(6.5)$ & 21.9 & $1.58 \mathrm{~s}$ & 29.2 \\
\hline 13 & $1.11 \mathrm{~d}(6.0)$ & 21.9 & $1.38 \mathrm{~s}$ & 29.5 \\
\hline 14 & $1.64 \mathrm{~s}$ & 10.7 & $1.68 \mathrm{~s}$ & 10.9 \\
\hline 15 & $2.10 \mathrm{~s}$ & 22.0 & $1.93 \mathrm{~s}$ & 22.4 \\
\hline Glc-1' & $4.92 \mathrm{~d}(8.0)$ & 104.6 & $4.87 \mathrm{~d}(8.0)$ & 105.5 \\
\hline Glc-2' & $3.96 \mathrm{t}(8.5)$ & 76.2 & $3.97 \mathrm{dd}(8.0,8.0)$ & 75.7 \\
\hline Glc-3' & $4.10 \mathrm{~m}$ & 78.4 & $4.21-4.15$ & 78.8 \\
\hline Glc-4' & $4.15 \mathrm{~m}$ & 72.1 & $4.01 \mathrm{dd}(9.5)$ & 72.1 \\
\hline Glc-5' & $3.86 \mathrm{~m}$ & 77.4 & 3.82 & 77.6 \\
\hline Glc-6' & $4.31 \mathrm{t}(6.0) / 4.47 \mathrm{dd}(11.5,3.0)$ & 63.4 & $4.38 \mathrm{~m} / 4.21-4.15$ & 64.0 \\
\hline Glc-1" & $4.99 \mathrm{~d}(8.0)$ & 102.1 & $4.99 \mathrm{~d}(8.0)$ & 102.2 \\
\hline Glc-2" & $4.64 \mathrm{~m}$ & 75.4 & $3.90 \mathrm{dd}(8.0,8.0)$ & 75.5 \\
\hline Glc-3" & $4.27 \mathrm{t}(9.0)$ & 78.1 & $4.21-4.15$ & 78.8 \\
\hline Glc-4" & $4.14 \mathrm{t}(4.0)$ & 71.6 & $4.10 \mathrm{~m}$ & 71.5 \\
\hline Glc-5" & $4.18 \mathrm{~d}(9.5)$ & 86.4 & $4.21-4.15$ & 79.3 \\
\hline Glc-6" & $4.41 \mathrm{dd}(12.0,6.0) / 4.64 \mathrm{~m}$ & 62.9 & $4.68 \mathrm{~m} / 4.42 \mathrm{~m}$ & 63.4 \\
\hline
\end{tabular}

a All assignments were supported with ${ }^{1} \mathrm{H}-{ }^{1} \mathrm{H}$ correlation spectroscopy $(\mathrm{COSY}),{ }^{1} \mathrm{H}_{-}{ }^{13} \mathrm{C}$ heteronuclear single quantum coherence spectroscopy (HSQC), and ${ }^{1} \mathrm{H}_{-}{ }^{13} \mathrm{C}$ heteronuclear multiple bond correlation (HMBC) experiments.

Based on the interpretation of ${ }^{1} \mathrm{H}$ - and ${ }^{13} \mathrm{C}-\mathrm{NMR}$ data of $\mathbf{1}$, it was inferred that $\mathbf{1}$ is a eudesmane-type sesquiterpene containing two glucopyranosyl moieties. An enzymatic hydrolysis of $\mathbf{1}$, high performance liquid chromatography (HPLC) experiment, and analysis of coupling constants (both $8.0 \mathrm{~Hz}$ ) of two anomeric protons led to the establishment of the sugars in $\mathbf{1}$ as $\beta$-D-glucopyranose. The heteronuclear multiple bond correlation (HMBC) experimental data showed long-range correlations between the signal of H-6 $\left(\delta_{\mathrm{H}} 4.64\right)$ and Glc-1' $\left(\delta_{\mathrm{C}} 104.6\right)$ and the signal of H-1 $\left(\delta_{\mathrm{H}} 4.18\right)$ and Glc-1" $\left(\delta_{\mathrm{C}} 102.1\right)$ (Figure S6), indicating that the positions of the glucopyranosyl moieties are $\mathrm{C}-1$ and $\mathrm{C}-2$. The positions of the three hydroxyl groups were also determined by HMBC correlations to be $C-1,6$, and 9 . The relative stereochemistry of the hydroxyl groups at $\mathrm{C}-1,6$, and 9 were determined as all $\beta$-forms on the basis of the NOESY correlations (H-1 with H-5, H-5 with H-6/H-7) (Figure 2, Figure S7). To make the 
stereochemistry of $\mathbf{1}$ clearer, we generated $\mathbf{2}$ by enzymatic hydrolysis of $\mathbf{1}$ (Figure 1 ). The NOESY spectra of 2 revealed correlations of $\mathrm{H}-1$ with $\mathrm{H}-9, \mathrm{H}-5$ with $\mathrm{H}-2 \alpha / \mathrm{H}-6 / \mathrm{H}-8 \alpha, \mathrm{H}-6$ with $\mathrm{H}-7$, and $\mathrm{H}-14$ with $\mathrm{H}-2 \beta / \mathrm{H}-8 \beta$ (Figure 2). To determine absolute configurations of $\mathbf{1}$ and $\mathbf{2}$, we obtained a derivative $\mathbf{1 a}$ by acidic hydrolysis of $\mathbf{1}$ (Figure 1). Additionally, an enzymatic hydrolysis of $1 \mathbf{a}$ was performed to remove the sugar moiety at C-1 and to produce $1 \mathbf{b}$ (Figure 1 ). In the ${ }^{1} \mathrm{H}$ - and ${ }^{13} \mathrm{C}-\mathrm{NMR}$ spectra of both molecules, there are similar signals that correspond to the protons of the eudesmane-type skeleton, except for the chemical shifts of the proton in C-1 in both $\mathbf{1 a}$ and $\mathbf{1 b}$, which are different due to the presence or absence of the sugar residue. The absolute configurations at $C-1,9$, and 10 of $\mathbf{1 b}$ were established by comparing its experimental ECD spectrum with calculated spectra of $(1 R, 9 S, 10 R)$ and $(1 S, 9 R, 10 S)$ models using the time-dependent density functional theory (TDDFT) method. The experimental ECD spectrum of $\mathbf{1 b}$ displayed a positive Cotton effect (CE) at $232 \mathrm{~nm}(\Delta \varepsilon+24.8)$. The experimental data were in good agreement with the calculated ECD spectrum of the $(1 R, 9 S, 10 R)$ model (Figure 3$)$, suggesting the absolute configuration of $\mathbf{1 b}$ as $(1 R, 9 S, 10 R)$. Therefore, the structure of the new compound $\mathbf{1}$ was elucidated as $(1 R, 5 S, 6 R, 7 S, 9 S, 10 S)$-1,6,9-trihydroxy-eudesm-3-ene-1,6-di-O- $\beta$-D-glucopyranoside.

A
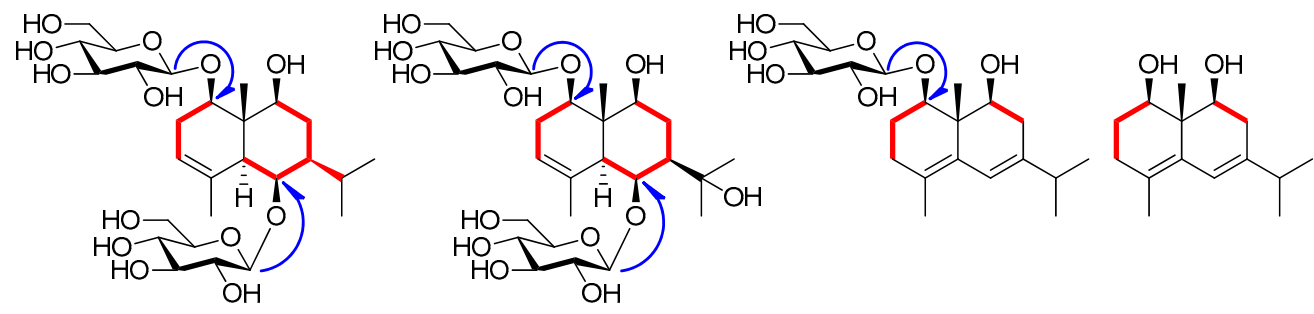

1

3

B

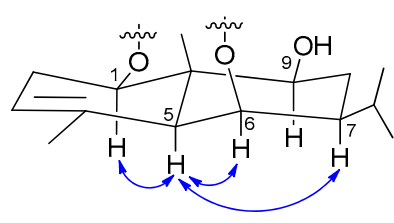

1

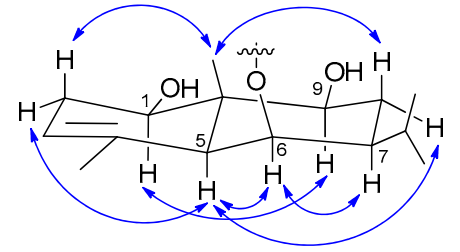

2
$1 a$

1b

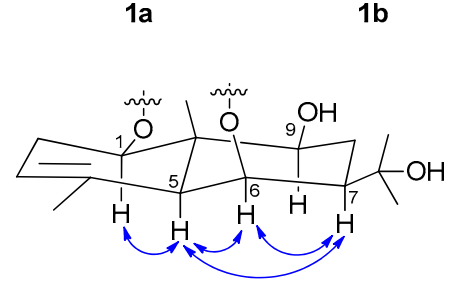

3

Figure 2. Key COSY $(-)$ and HMBC $(\longrightarrow$ ) correlations of $\mathbf{1}, \mathbf{3}, \mathbf{1 a}$, and $\mathbf{1 b}(\mathbf{A})$. Key NOESY $(\ulcorner)$ correlations of $\mathbf{1}, \mathbf{2}$, and 3 (B).

A

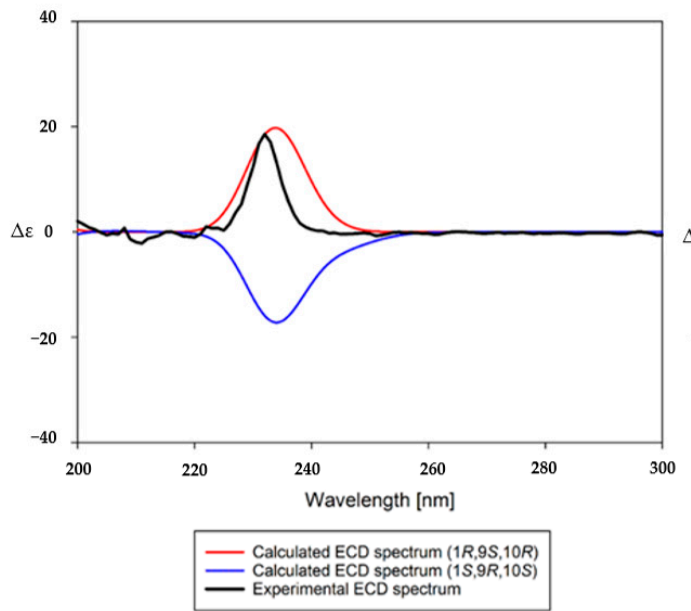

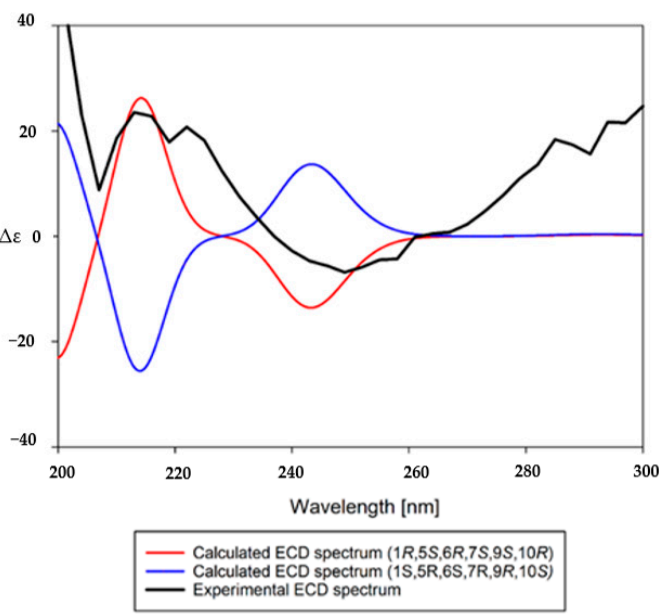

Figure 3. Measured and calculated electronic circular dichroism (ECD) spectra of $\mathbf{1 b}(\mathbf{A})$ and $\mathbf{5}$ (B). 
The planar structure of 2 turned out to be the same as $1 \beta, 6 \beta, 9 \alpha$ -trihydroxy-trans-eudesm-3-ene-6-O- $\beta$-D-glucopyranoside, which was isolated previously from the flower of $A$. koraiensis and reported only its relative configuration [4]. Although their ${ }^{1} \mathrm{H}$ - and ${ }^{13} \mathrm{C}-\mathrm{NMR}$ spectroscopic data were identical, indicating they are the same compounds, we found that 2 has different

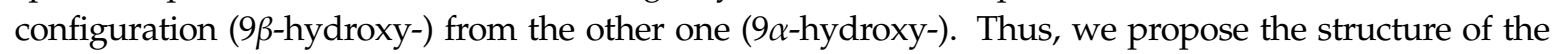
known compound 2 as $(1 R, 5 S, 6 R, 7 S, 9 S, 10 R)-1,6,9$-trihydroxy-eudesm-3-ene-6-O- $\beta$-D-glucopyranoside.

Compound $\mathbf{3}$ was isolated as a white powder. The molecular formula of $\mathbf{3}$ was established as $\mathrm{C}_{27} \mathrm{H}_{46} \mathrm{O}_{14}$ by HR-ESI-MS $\left(m / z=617.2791[\mathrm{M}+\mathrm{Na}]^{+}\right.$; calcd for $\left.\mathrm{C}_{27} \mathrm{H}_{46} \mathrm{O}_{14} \mathrm{Na}, 617.2785\right)$ (Figure S15). The ${ }^{1} \mathrm{H}-\mathrm{NMR}$ spectrum of 3 exhibited two singlet methyl signals at $\delta_{\mathrm{H}} 1.58(3 \mathrm{H})$ and $1.38(3 \mathrm{H})$, two anomeric protons at $\delta_{\mathrm{H}} 4.99(1 \mathrm{H}, \mathrm{d}, J=8.0 \mathrm{~Hz})$ and $4.87(1 \mathrm{H}, \mathrm{d}, J=8.0 \mathrm{~Hz})$, and an olefinic proton at $\delta_{\mathrm{H}} 4.98\left(1 \mathrm{H}, \mathrm{br}\right.$ s) (Table 1, Figure S16). The ${ }^{13} \mathrm{C}-\mathrm{NMR}$ spectrum of 3 showed 27 signals including four methyl carbons $\left(\delta_{C} 29.5,29.2,22.4\right.$, and 10.9), two methylene carbons $\left(\delta_{C} 28.5\right.$ and 27.3), 12 signals for glucose moieties, and three quaternary carbons $\left(\delta_{C} 136.7,72.6\right.$, and 42.9$)$ (Table 1 , Figure S17). The NMR data for $\mathbf{3}$ were very similar to $\mathbf{1}$ except for the presence of a quaternary oxygenated carbon signal instead of a methine carbon signal. The position of the quaternary carbon at $\mathrm{C}-11$ was deduced on the basis of the coupling pattern for two methyl groups changed from $\left(\delta_{\mathrm{H}} 1.11(3 \mathrm{H}, \mathrm{d}, J=6.0 \mathrm{~Hz})\right.$ and $\left.0.85(3 \mathrm{H}, \mathrm{d}, J=6.5 \mathrm{~Hz})\right)$ to $\left(\delta_{\mathrm{H}} 1.58(3 \mathrm{H}, \mathrm{s})\right.$ and $\left.1.38(3 \mathrm{H}, \mathrm{s})\right)$ in the ${ }^{1} \mathrm{H}-\mathrm{NMR}$ spectrum. It was supported by HMBC correlations between the signal of $\mathrm{C}-11$ and $\mathrm{H}-12, \mathrm{H}-13$, and H-7 (Figure S20). The relative stereochemistry of hydroxyl groups at C-1, 6, and 9 were determined as all $\beta$-forms like 1 by analyzing NOESY correlations ( $\mathrm{H}-1$ with $\mathrm{H}-5, \mathrm{H}-5$ with $\mathrm{H}-6 / \mathrm{H}-7$, and H-6 with H-7), indicating 3 is a 11-hydroxy derivative of 1 (Figure 2, Figure S21). Considering a biogenetic relationship with 1 , the structure of the new compound 3 was proposed as $(1 R, 5 S, 6 S, 7 R, 9 S, 10 S)-1,6,9,11$-tetrahydroxy-eudesm-3-ene-1,6-di-O- $\beta$-D-glucopyranoside.

The planar structure of 4 was also reported from the flowers of A. koraiensis together with 2 (Figure 2) [4]. The authors reported the chemical structure of the compound as $1 \beta, 6 \beta, 9 \alpha, 11$-tetrahydroxy-trans-eudesm-3-ene-6-O- $\beta$-D-glucopyranoside on the basis of the NOESY experiment. The ${ }^{1} \mathrm{H}$ - and ${ }^{13} \mathrm{C}-\mathrm{NMR}$ spectroscopic data of 4 were identical with those of published values [4]. However, the NOESY correlations indicated that the relative configuration of 4 is the same as 1-3. Therefore, we propose the structure of the known compound 4 as $(1 R, 5 S, 6 S, 7 R, 9 S, 10 R)-1,6,9,11$-tetrahydroxy-eudesm-3-ene-6-O- $\beta$-D-glucopyranoside.

Compound 6 was obtained as a pale yellow amorphous powder and the molecular formula was established as $\mathrm{C}_{30} \mathrm{H}_{42} \mathrm{O}_{10}$ by HR-ESI-MS $\left(m / z 561.2710[\mathrm{M}-\mathrm{H}]^{-}\right.$, calcd for $\left.\mathrm{C}_{30} \mathrm{H}_{41} \mathrm{O}_{10}, 561.2705\right)$ (Figure S15). The ${ }^{1} \mathrm{H}-\mathrm{NMR}$ spectrum of 6 showed four methyl signals at $\delta_{\mathrm{H}} 1.88(3 \mathrm{H}, \mathrm{s}), 1.26(3 \mathrm{H}, \mathrm{s})$, $1.02(3 \mathrm{H}, \mathrm{d}, J=6.5 \mathrm{~Hz})$, and $0.93(3 \mathrm{H}, \mathrm{d}, J=6.5 \mathrm{~Hz})$; one anomeric proton at $\delta_{\mathrm{H}} 4.38(1 \mathrm{H}, \mathrm{d}, J=8.0 \mathrm{~Hz}$; and cis-olefinic group at $\delta_{\mathrm{H}} 6.89(1 \mathrm{H}, \mathrm{d}, J=12.5 \mathrm{~Hz})$ and $5.80(1 \mathrm{H}, \mathrm{d}, J=12.5 \mathrm{~Hz})$ (Table 2, Figure S16). The ${ }^{13} \mathrm{C}-\mathrm{NMR}$ spectrum of 6 exhibited four methyl signals $\left(\delta_{\mathrm{C}} 22.0,21.9,21.8\right.$, and 11.8), six glucosyl signals including an anomeric carbon $\left(\delta_{\mathrm{C}} 104.5,78.5,77.5,76.2,72.1\right.$, and 63.3$)$, three oxymethine signals $\left(\delta_{C} 80.8,80.3\right.$, and 76.0), and cis-para-coumaroyl group $\left(\delta_{C} 167.8,160.3,145.7,134.2 \times 2,127.9,117.7\right.$, and $116.0 \times 2$ ), indicating that 6 is a $p$-coumaroyl derivative of 2 (Table 2, Figure S17). The positions of hydroxyl, $p$-coumaroyl and $\beta$-D-glucopyranosyl groups and the relative configurations were determined by analysis of the HMBC and NOESY correlations (Figure 4, Figures S20 and S21). On the basis of the NMR data and a biogenetic relationship with 1-4, the structure of the new compound 6 was proposed as $(1 R, 5 S, 6 R, 7 S, 9 S, 10 R)$-9-O-(Z-p-coumaroyl)-1,6,9-trihydroxy-eudesm-3-en-6-O- $\beta$-D-glucopyranoside. A literature survey revealed that $\mathbf{6}$ is the geometric isomer of 5, $9 \beta$-O-(E-p-hydroxycinnamoyl)-1 $\beta, 6 \beta$-dihydroxy-trans-eudesm-3-ene-6-O- $\beta$-D-glucopyranoside, which was isolated previously from the aerial parts of $A$. koraiensis and reported only its relative configuration [16]. The absolute configuration of $\mathbf{5}$ was established by comparing its experimental ECD spectrum with those calculated spectra of $(1 R, 5 S, 6 R, 7 S, 9 S, 10 R)$ and $(1 S, 5 R, 6 S, 7 R, 9 R, 10 S)$ models using the same method as 1c. The experimental data (Figure 3) were in accordance with the calculated ECD spectrum of the $(1 R, 5 S, 6 R, 7 S, 9 S, 10 R)$ model, offering the absolute configuration of 5 as 
(1R,5S,6R,7S,9S,10R)-9-O-(E-p-coumaroyl)-1,6,9-trihydroxy-eudesm-3-ene-6-O- $\beta$-D-glucopyranoside and also supporting our proposed absolute configurations for 1-6.

Table 2. ${ }^{1} \mathrm{H}$ and ${ }^{13} \mathrm{C}$ NMR spectroscopic data of 6 and 7 ( $\delta$ in ppm, $\mathrm{CD}_{3} \mathrm{OD}, 500$, and $\left.125 \mathrm{MHz}\right)$.

\begin{tabular}{|c|c|c|c|c|}
\hline \multirow{2}{*}{ Position ${ }^{a}$} & \multicolumn{2}{|l|}{6} & \multicolumn{2}{|l|}{7} \\
\hline & $\delta_{\mathrm{H}}$ Multi $(J$ in $\mathrm{Hz})$ & $\delta_{\mathrm{C}}$ & $\delta_{\mathrm{H}}$ Multi $(J$ in $\mathrm{Hz})$ & $\delta_{\mathrm{C}}$ \\
\hline 1 & 4.87 overlapped & 80.8 & 4.89 overlapped & 80.5 \\
\hline 2 & $2.22 \mathrm{~m} / 2.09 \mathrm{~m}$ & 29.6 & $2.25 \mathrm{~m} / 2.09 \mathrm{~m}$ & 29.7 \\
\hline 3 & $5.29 \mathrm{br} \mathrm{s}$ & 120.4 & $5.30 \mathrm{br} \mathrm{s}$ & 120.7 \\
\hline 4 & & 136.2 & & 136.0 \\
\hline 5 & 2.10 br s & 52.3 & 2.11 br s & 52.4 \\
\hline 6 & $4.46 \mathrm{~s}$ & 76.0 & $4.47 \mathrm{~s}$ & 76.0 \\
\hline 7 & $1.18 \mathrm{~m}$ & 51.5 & $1.18 \mathrm{~m}$ & 51.5 \\
\hline 8 & $1.98 \mathrm{~m}$ & 29.1 & $1.93 \mathrm{~m}$ & 29.1 \\
\hline 9 & 4.92 overlapped & 80.3 & 4.98 overlapped & 80.4 \\
\hline 10 & & 42.2 & & 42.3 \\
\hline 11 & $1.89 \mathrm{~m}$ & 29.0 & $1.98 \mathrm{~m}$ & 29.1 \\
\hline 12 & $1.02 \mathrm{~d}(6.5)$ & 21.9 & $1.02 \mathrm{~d}(6.5)$ & 21.9 \\
\hline 13 & $0.93 \mathrm{~d}(6.5)$ & 21.8 & $0.92 \mathrm{~d}(6.5)$ & 21.8 \\
\hline 14 & $1.26 \mathrm{~s}$ & 11.8 & $1.37 \mathrm{~s}$ & 11.9 \\
\hline 15 & $1.88 \mathrm{~s}$ & 22.0 & $1.87 \mathrm{~s}$ & 22.0 \\
\hline Glc-1' & $4.38 \mathrm{~d}(8.0)$ & 104.5 & $4.39 \mathrm{~d}(8.0)$ & 104.5 \\
\hline Glc-2' & 3.14 br t (8.5) & 76.2 & 3.16 br t $(8.0)$ & 76.2 \\
\hline Glc-3' & $3.32 \mathrm{~m}$ & 78.5 & $3.32 \mathrm{~m}$ & 78.5 \\
\hline Glc- $4^{\prime}$ & $3.31 \mathrm{~m}$ & 72.1 & $3.31 \mathrm{~m}$ & 72.1 \\
\hline Glc-5' & $3.21 \mathrm{~m}$ & 77.5 & $3.21 \mathrm{~m}$ & 77.6 \\
\hline Glc-6' & $\begin{array}{c}3.83 \mathrm{dd}(11.5,2.5) / 3.68 \\
\mathrm{dd}(11.5,5.5)\end{array}$ & 63.3 & $\begin{array}{c}3.83 \mathrm{dd}(11.5,2.5) / 3.69 \\
\operatorname{dd}(11.5,5.5)\end{array}$ & 63.3 \\
\hline $1^{\prime \prime}$ & & 127.9 & & 124.5 \\
\hline $2^{\prime \prime}$ & $7.70 \mathrm{~d}(8.5)$ & 134.2 & $7.22 \mathrm{~d}(2.0)$ & 111.9 \\
\hline $3^{\prime \prime}$ & $6.76 \mathrm{~d}(8.5)$ & 116.0 & $7.08 \mathrm{dd}(8.5,2.0)$ & 120.7 \\
\hline $4^{\prime \prime}$ & & 160.3 & & 149.6 \\
\hline $5^{\prime \prime}$ & $6.76 \mathrm{~d}(8.5)$ & 116.0 & $6.81 \mathrm{~d}(8.5)$ & 116.7 \\
\hline $6^{\prime \prime}$ & $7.70 \mathrm{~d}(8.5)$ & 134.2 & & 150.8 \\
\hline $7^{\prime \prime}$ & $6.89 \mathrm{~d}(12.5)$ & 145.7 & $7.61 \mathrm{~d}(16.0)$ & 147.0 \\
\hline $8^{\prime \prime}$ & $5.80 \mathrm{~d}(12.5)$ & 117.7 & $6.38 \mathrm{~d}(16.0)$ & 116.7 \\
\hline $9^{\prime \prime}$ & & 167.8 & & 168.8 \\
\hline $\mathrm{OCH}_{3}$ & - & - & $3.91 \mathrm{~s}$ & 56.7 \\
\hline
\end{tabular}

a All assignments were supported with COSY, HSQC, and HMBC experiments.

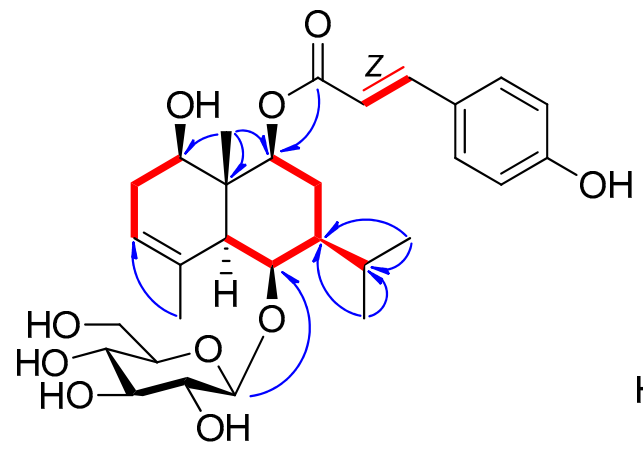

6

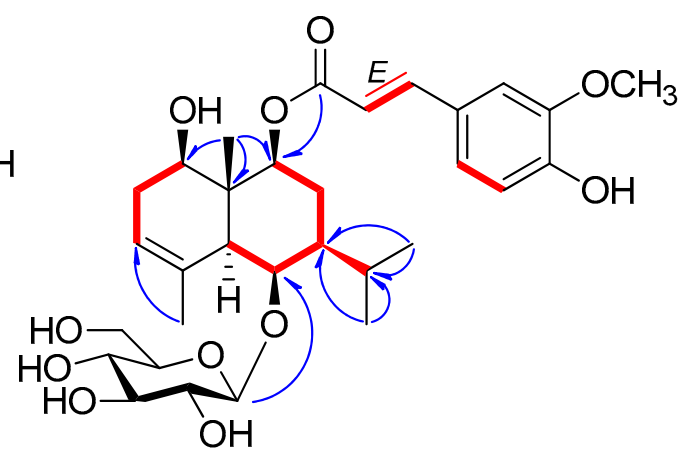

7

Figure 4. Key ${ }^{1} \mathrm{H}^{-1} \mathrm{H} \operatorname{COSY}(-)$ and $\mathrm{HMBC}(\longrightarrow)$ correlations of 6 and 7. 
The molecular formula of 7 was established as $\mathrm{C}_{31} \mathrm{H}_{44} \mathrm{O}_{11}$ by HR-ESI-MS $(\mathrm{m} / z$ 575.2848 [M- $\left.\mathrm{H}_{2} \mathrm{O}-\mathrm{H}\right]^{-}$, calcd for $\mathrm{C}_{31} \mathrm{H}_{43} \mathrm{O}_{10}, 575.2856$ ) (Figure S22). The ${ }^{1} \mathrm{H}-$ and ${ }^{13} \mathrm{C}-\mathrm{NMR}$ spectroscopic data of 7 were very similar with those of 5 and $\mathbf{6}$ except for the presence of $E$-p-feruloyl group in 7 instead of $E$ - or Z-p-coumaroyl group (Table 2). An ABX system $\left(\delta_{\mathrm{H}} 6.81(\mathrm{~d}, J=8.5 \mathrm{~Hz}), 7.08(\mathrm{dd}\right.$, $J=8.5,2.0 \mathrm{~Hz})$, and $7.22(\mathrm{~d}, J=2.0 \mathrm{~Hz}))$, trans-olefinic group $\left(\delta_{\mathrm{H}} 7.61(1 \mathrm{H}, \mathrm{d}, J=16.0 \mathrm{~Hz})\right.$ and $6.38(1 \mathrm{H}$, $\mathrm{d}, J=16.0 \mathrm{~Hz}))$, and a methoxy signal $\left(\delta_{\mathrm{H}} 3.91(3 \mathrm{H}, \mathrm{s})\right)$ were revealed in the ${ }^{1} \mathrm{H}-\mathrm{NMR}$ spectrum of 7 , indicating the presence of $E$-p-feruloyl group in 7 . The positions of the functional groups in 7 and the relative configuration were confirmed by the HMBC and NOESY correlations (Figure 4, Figures S26 and S27). Thus, from the analysis of above data, the structure of the new compound 7 was elucidated as $(1 R, 5 S, 6 R, 7 S, 9 S, 10 R)-9-O-(E-p$-feruloyl)-1,6,9-trihydroxy-eudesm-3-ene-6-O- $\beta$-D-glucopyranoside.

The structures of other known compounds were identified as 3,5-dicaffeoylquinic acid (8) [20] and 4,5-dicaffeoylquinic acid (9) [20] by comparison of their NMR data with those reported.

Although numerous types of sesquiterpene have been reported from the Compositae family, until now, only eudesmane-type sesquiterpenes have been isolated from A. koraiensis [15-17], except for the presence of an oplopane-type sesquiterpene [15].

\subsection{Inhibitory Activities of the Isolates on LPS-Stimulated NO and PGE 2 Production}

All the isolates 1-9 obtained from the leaves of $A$. koraiensis were evaluated for their inhibitory effects of LPS-stimulated NO and $\mathrm{PGE}_{2}$ production in RAW 264.7 macrophages at non-toxic concentrations (Table 3). Of these, only the new compound 7 presented weak inhibitory effects on both $\mathrm{NO}$ and $\mathrm{PGE}_{2}$ production with observed $\mathrm{IC}_{50}$ values of 95.7 and $111.6 \mu \mathrm{M}$, respectively, while others were inactive (Table 3, Figure 5).

Table 3. The cytotoxicities and inhibitory activities of 1-9 obtained from the leaves of $A$. koraiensis on LPS-induced NO and $\mathrm{PGE}_{2}$ production in RAW 264.7 macrophages.

\begin{tabular}{cccc}
\hline \multirow{2}{*}{ Compound } & Cell Viabilities (\%) & a & \multicolumn{2}{c}{ Inhibition Rate $(\%)^{\mathbf{a}}{ }^{\left[I_{\mathbf{5 0}}(\mu \mathbf{M})\right]}$} \\
\cline { 3 - 4 } & & NO & PGE $_{\mathbf{2}}$ \\
\hline $\mathbf{1}$ & 102.46 & $1.79[>100]$ & $0[>100]$ \\
$\mathbf{2}$ & 105.31 & $3.20[>100]$ & $0[>100]$ \\
$\mathbf{3}$ & 94.03 & $4.66[>100]$ & $10.48[>100]$ \\
$\mathbf{4}$ & 102.18 & $1.31[>100]$ & $6.15[>100]$ \\
$\mathbf{5}$ & 103.83 & $8.39[>100]$ & $0[>100]$ \\
$\mathbf{6}$ & 107.78 & $7.01[>100]$ & $2.16[>100]$ \\
$\mathbf{7}$ & 89.35 & $53.12[95.7]$ & $41.26[111.6]$ \\
$\mathbf{8}$ & 93.38 & $6.25[>100]$ & $1.27[>100]$ \\
$\mathbf{9}$ & 100.41 & $4.64[>100]$ & $20.42[>100]$ \\
\hline
\end{tabular}

${ }^{a}$ Cells were pretreated with 1-9 $(100 \mu \mathrm{M})$ and LPS $(1 \mu \mathrm{g} / \mathrm{mL})$ for $1 \mathrm{~h}$, and incubated for $24 \mathrm{~h}$. 
A

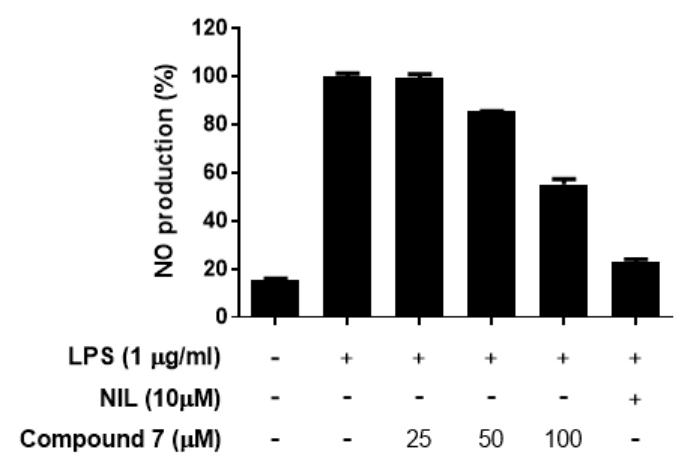

B

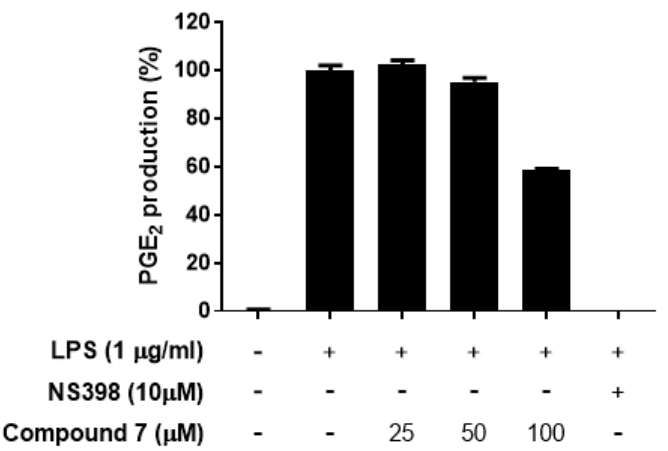

Figure 5. Inhibitory effects of compound 7 on LPS-stimulated $\mathrm{NO}(\mathbf{A})$ and $\mathrm{PGE}_{2}$ productions (B) in RAW 264.7 macrophages. Cells were pretreated with different concentrations $(25,50$, or $100 \mu \mathrm{M})$ of compound 7 for $1 \mathrm{~h}$, then with LPS $(1 \mu \mathrm{g} / \mathrm{mL})$, and then were incubated for $24 \mathrm{~h}$. 1- $N^{6}$-(1-Iminoethyl)lysine (1-NIL, $10 \mu \mathrm{M})$ and $N$-[2-(cyclohexyloxy)-4-nitrophenyl]-methanesulfonamide (NS-398, $10 \mu \mathrm{M}$ ) were used as positive $\mathrm{NO}$ and $\mathrm{PGE}_{2}$ production inhibitors, respectively.

\section{Materials and Methods}

\subsection{Plant Material}

The leaves of Aster koraiensis Nakai (Compositae) were collected at Pyeongchang, Gangwon-Do, Korea, in 2017. The origin of the plant was authenticated by one of the authors D.S.J. and a voucher specimen (ASKO1-2017) was deposited at the College of Pharmacy, Kyung Hee University, Korea.

\subsection{General Experimental Procedures}

General experimental procedures are in the Supplementary Materials.

\subsection{Extraction and Isolation}

The dried and ground leaves $(5.0 \mathrm{~kg})$ of $A$. koraiensis were extracted twice with $25 \mathrm{~L}$ of $95 \%$ $\mathrm{EtOH}$ at $70{ }^{\circ} \mathrm{C}$ for 3 hours and extract solutions were condensed using a steam heated evaporator. The 95\% EtOH extract (500 g) was chromatographed over Diaion HP-20 $(9.8 \times 63.0 \mathrm{~cm})$ eluting with an acetone- $\mathrm{H}_{2} \mathrm{O}$ gradient (from 0:1 to 1:0 v/v) to afford 28 fractions (C1 C28).

Fraction C4 (11.82 g) was separated into five subfractions by Sephadex LH-20 column chromatography $(\mathrm{CC})(4.8 \times 63.0 \mathrm{~cm})$ with $50 \%$ acetone $(\mathrm{C} 4-1 \sim \mathrm{C} 4-5)$. Compound $3(18.7 \mathrm{mg})$ was purified by repetitive chromatography from subfraction C4-2 $(2.99 \mathrm{~g})$. Fraction C5 (8.32 g) was fractionated further by Sephadex LH-20 CC $(4.8 \times 43.0 \mathrm{~cm})$ with $\mathrm{MeOH}-\mathrm{H}_{2} \mathrm{O}(1: 1 \mathrm{v} / \mathrm{v})$, yielding 14 fractions (C5-1 C5-14) and compound $1(1.76 \mathrm{~g})$. Compound 4 (61.3 mg) was purified using a flash chromatography system (Redi Sep-C18 cartridge, $43 \mathrm{~g}, \mathrm{MeOH}-\mathrm{H}_{2} \mathrm{O}$ gradient (from 10:90 to 40:60 v/v)) from fraction C5-3-5 (133.8 mg). Compound $1(324.1 \mathrm{mg})$ was additionally obtained by flash chromatography with Redi Sep-C18 cartridge $\left(120 \mathrm{~g}, \mathrm{MeOH}-\mathrm{H}_{2} \mathrm{O}\right.$, from 20:80 to 50:50 v/v) from fraction C5-3-11 (701.6 mg). Fraction C9 (3.64 g) was subjected to Sephadex LH-20 CC with a $\mathrm{MeOH}-\mathrm{H}_{2} \mathrm{O}$ mixture (1:1 v/v) to give nine subfractions (C9-1 C9-9). Subfraction C9-5 (522.9 mg) was separated further using a flash chromatography system with Redi Sep-C18 (43 g, MeOH- $\mathrm{H}_{2} \mathrm{O}, 40: 60$ to $70: 30, v / v)$ to afford compound $2(41.8 \mathrm{mg})$. Fraction C11 (10.0 g) was separated into seven subfractions (C11-1 C11-7) by Sephadex LH-20 CC $(3.6 \times 65.0 \mathrm{~cm})$ with 50\% acetone. Subfraction C11-6 $(2.27 \mathrm{~g})$ was chromatographed over silica gel (230-400 mesh; $4.8 \times 28.3 \mathrm{~cm}$ ) with an EtOAc-acetone- $\mathrm{H}_{2} \mathrm{O}$ mixture (from 50:45:5 to 30:60:10 v/v/v) as mobile phase to obtain compounds 8 (948.8 mg) and $9(10.2 \mathrm{mg}$ ). Fraction C17 (3.12 g) was fractionated into five subfractions (C17-1 C17-5) by Sephadex LH-20 CC $(4.0 \times 69.0 \mathrm{~cm})$ with $\mathrm{MeOH}-\mathrm{H}_{2} \mathrm{O}(1: 1 \mathrm{v} / \mathrm{v})$. Compounds $5(25.6 \mathrm{mg}), 6(7.6 \mathrm{mg})$, and $7(4.8 \mathrm{mg})$ were 
isolated from subfraction C17-3 $(300.0 \mathrm{mg})$ using a flash chromatography system with silica cartridge (48 g, $\mathrm{CH}_{2} \mathrm{Cl}_{2}-\mathrm{MeOH}-\mathrm{H}_{2} \mathrm{O}, 35: 65$ to 50:50, v/v).

\subsection{1. (1R,5S,6R,7S,9S,10S)-1,6,9-trihydroxy-eudesm-3-ene-1,6-di-O- $\beta$-D-glucopyranoside (1)}

White powder; m.p.: $167.2^{\circ} \mathrm{C} ;[\alpha]_{\mathrm{D}}^{20}:-0.4^{\circ}(c 0.1, \mathrm{MeOH})$; UV (acetonitrile) $\lambda_{\max }(\log \varepsilon): 205$ (3.83), $376(4.08) \mathrm{nm}$; IR (ATR) $v_{\max } 3437,2917,1358,1010 \mathrm{~cm}^{-1}$; HR-ESI-MS $\mathrm{m} / z=601.2838\left[\mathrm{M}+\mathrm{Na}^{+}\right.$, (calcd for $\mathrm{C}_{27} \mathrm{H}_{46} \mathrm{O}_{13} \mathrm{Na}$, 601.2836); NMR data: Table 1 .

\subsection{2. $1 R, 9 S, 10 S-1,9-D i h y d r o x y-e u d e s m-4,6-d i e n e-1-O-\beta$-D-glucopyranoside (1a)}

Pale yellow amorphous powder; HR-Q-TOF-MS m/z $=397.2237$ [M-H] $]^{-}$(calcd for $\mathrm{C}_{21} \mathrm{H}_{33} \mathrm{O}_{7}$, 397.2226); $[\alpha]_{\mathrm{D}}^{20}: 58.3^{\circ}$ (c 0.03, MeOH); UV (MeOH) $\lambda_{\max } \mathrm{nm}(\log \varepsilon): 240$ (3.37), 296 (3.34); IR (ATR) $v_{\max } 1937,1587,1348,1013 \mathrm{~cm}^{-1} ;{ }^{1} \mathrm{H}-\mathrm{NMR}\left(500 \mathrm{MHz}, \mathrm{CD}_{3} \mathrm{OD}\right) \delta_{\mathrm{H}} 6.05(1 \mathrm{H}, \mathrm{brs}, \mathrm{H}-6), 4.48(1 \mathrm{H}, \mathrm{d}$, $J=8.0 \mathrm{~Hz}, \mathrm{Glc}-1), 3.94(1 \mathrm{H}, \mathrm{dd}, J=12.0,4.0 \mathrm{~Hz}, \mathrm{H}-1), 3.88(1 \mathrm{H}, \mathrm{dd}, J=12.0,2.0 \mathrm{~Hz}, \mathrm{Glc}-6 \mathrm{a}), 3.83(1 \mathrm{H}$, dd, $J=11.0,5.5 \mathrm{~Hz}, \mathrm{H}-9), 3.65$ (1H, dd, $J=12.0,6.0 \mathrm{~Hz}, \mathrm{Glc}-6 \mathrm{~b}), 3.36$ (1H, m, Glc-5), 3.29 (1H, m, Glc-4), $3.27(1 \mathrm{H}, \mathrm{m}, \mathrm{Glc}-3), 3.17(1 \mathrm{H}, \mathrm{dd}, J=9.5,8.0 \mathrm{~Hz}, \mathrm{Glc}-2), 2.31(1 \mathrm{H}, \mathrm{m}, \mathrm{H}-11), 2.19(2 \mathrm{H}, \mathrm{m}, \mathrm{H}-8), 2.08(2 \mathrm{H}$, $\mathrm{m}, \mathrm{H}-3), 1.93(2 \mathrm{H}, \mathrm{m}, \mathrm{H}-2), 1.69$ (3H, s, H-15), 1.07 (3H, d, J = 2.0 Hz, H-12), 1.06 (3H, d, J = 2.0 Hz, H-13), $1.01(3 \mathrm{H}, \mathrm{s}, \mathrm{H}-14) ;{ }^{13} \mathrm{C}-\mathrm{NMR}\left(125 \mathrm{MHz}, \mathrm{CD}_{3} \mathrm{OD}\right) \delta_{\mathrm{C}} 141.9$ (C-7), 133.3 (C-5), 129.1 (C-4), 118.5 (C-6), 102.4 (Glc-1), 84.9 (C-1), 78.6 (Glc-5), 78.3 (Glc-3), 78.1 (C-9), 75.1 (Glc-2), 71.7 (Glc-4), 63.0 (Glc-6), 43.1 (C-10), 36.4 (C-11), 33.0 (C-8), 32.5 (C-3), 24.6 (C-2), 22.2 (C-12), 21.7 (C-13), 19.2 (C-15), 12.5 (C-14).

\subsection{3. $1 R, 9 S, 10 R$-1,9-Dihydroxy-eudesm-4,6-diene (1b)}

Pale yellow amorphous powder; $[\alpha]_{\mathrm{D}}^{20}: 67.2^{\circ}($ c $0.03, \mathrm{MeOH}) ; \mathrm{UV}(\mathrm{MeOH}) \lambda_{\max } \mathrm{nm}(\log \varepsilon)$ : 239 (3.27), 290 (3.22); IR (ATR) $v_{\max } 1569,1418,1363,1016 \mathrm{~cm}^{-1} ;{ }^{1} \mathrm{H}-\mathrm{NMR}\left(500 \mathrm{MHz}, \mathrm{CD}_{3} \mathrm{OD}\right) \delta_{\mathrm{H}} 6.07$ $(1 \mathrm{H}$, brs, H-6), $3.77(1 \mathrm{H}, \mathrm{dd}, J=12.0,4.0 \mathrm{~Hz}, \mathrm{H}-1), 3.68(1 \mathrm{H}, \mathrm{dd}, J=11.0,5.5 \mathrm{~Hz}, \mathrm{H}-9), 2.30(1 \mathrm{H}, \mathrm{m}$, H-11), 2.22 (2H, m, H-8), $2.14(2 \mathrm{H}, \mathrm{m}, \mathrm{H}-3), 1.80$ (2H, m, H-2), 1.68 (3H, s, H-15), $1.07(3 \mathrm{H}, \mathrm{d}, J=2.0 \mathrm{~Hz}$, $\mathrm{H}-12), 1.05(3 \mathrm{H}, \mathrm{d}, J=2.0 \mathrm{~Hz}, \mathrm{H}-13), 0.93(3 \mathrm{H}, \mathrm{s}, \mathrm{H}-14) ;{ }^{13} \mathrm{C}-\mathrm{NMR}\left(125 \mathrm{MHz}, \mathrm{CD}_{3} \mathrm{OD}\right) \delta_{\mathrm{C}} 141.9$ (C-7), 133.3 (C-5), 129.1 (C-4), 118.5 (C-6), 78.6 (C-1), 78.3 (C-9), 43.1 (C-10), 36.4 (C-11), 33.0 (C-8), 32.5 (C-3), 24.6 (C-2), 22.2 (C-12), 21.7 (C-13), 19.2 (C-15), 12.5 (C-14).

\subsection{4. (1R,5S,6S,7R,9S,10S)-1,6,9,11-tetrahydroxy-eudesm-3-ene-1,6-di-O- $\beta$-D-glucopyranoside (3)}

White powder; m.p.: $230^{\circ} \mathrm{C} ;[\alpha]_{\mathrm{D}}^{20}:-1.5^{\circ}(c 0.1, \mathrm{MeOH}) ; \mathrm{UV}$ (acetonitrile) $\lambda_{\max }(\log \varepsilon): 205$ (3.85), 322 (4.02), 359 (4.08), 373 (4.43) nm; IR (ATR) $v_{\max } 3314,2876,1360,1011 \mathrm{~cm}^{-1}$; HR-ESI-MS (positive mode) $m / z=617.2791[\mathrm{M}+\mathrm{Na}]^{+}$(calcd for $\mathrm{C}_{27} \mathrm{H}_{46} \mathrm{O}_{14} \mathrm{Na}, 617.2785$ ); NMR data: Table 1.

3.3.5. (1R,5S,6R,7S,9S,10R)-O-(Z-p-coumaroyl)-1,6,9-Trihydroxy-eudesm-3-ene-6-O- $\beta$-D -glucopyranoside (6)

Pale yellow amorphous powder; HR-ESI-MS $m / z=561.2701[\mathrm{M}-\mathrm{H}]^{-}$(calcd for $\mathrm{C}_{30} \mathrm{H}_{41} \mathrm{O}_{10}$, 561.2705); $[\alpha]_{\mathrm{D}}^{20}: 48.4^{\circ}\left(c\right.$ 0.1, MeOH); UV (MeOH) $\lambda_{\max } \mathrm{nm}(\log \varepsilon): 313$ (4.48); IR (ATR) $v_{\max } 1705$, $16031513,1165,1074,989 \mathrm{~cm}^{-1}$; NMR data: Table 2.

\subsection{6. (1R,5S,6R,7S,9S,10R)-O-(E-feruloyl)-1,6,9-Trihydroxy-eudesm-3-ene-6-O- $\beta$-D-glucopyranoside (7)}

Pale yellow amorphous powder; HR-ESI-MS $m / z=575.2845\left[\mathrm{M}-\mathrm{H}_{2} \mathrm{O}-\mathrm{H}\right]^{-}$(calcd for $\mathrm{C}_{31} \mathrm{H}_{43} \mathrm{O}_{10}$, 575.2856); $[\alpha]_{\mathrm{D}}^{20}: 5.8^{\circ}$ (c 0.1, MeOH); UV (MeOH) $\lambda_{\max } \mathrm{nm}(\log \varepsilon): 237$ (3.47), 327 (3.22); IR (ATR) $v_{\max }$ $1705,1596,1517,1268,1159,1074 \mathrm{~cm}^{-1}$; NMR data: Table 2.

\subsection{Acidic and Enzymatic Hydrolysis of 1}

Compound $1(10.0 \mathrm{mg})$ was incubated together with $\beta$-glucosidase $(25.0 \mathrm{mg})$, toluene ( 2 drops), and $\mathrm{H}_{2} \mathrm{O}(15.0 \mathrm{~mL})$ in a $\mathrm{CO}_{2}$ incubator at $35^{\circ} \mathrm{C}$ for 3 days. $\mathrm{EtOH}$ was added to the reaction mixture to stop the reaction and $\beta$-glucosidase was removed by filtration. Compound $2(2.0 \mathrm{mg})$ was isolated from 
the hydrolysate by flash CC with Redi Sep-C18 cartridge $\left(13 \mathrm{~g}, \mathrm{MeOH}-\mathrm{H}_{2} \mathrm{O}\right.$, from 50:50 to 80:20 v/v). Meanwhile, compound $\mathbf{1}(93.8 \mathrm{mg})$ was hydrolyzed with $2 \mathrm{~N} \mathrm{HCl}$ at $80^{\circ} \mathrm{C}$ for one hour. The reaction was stopped by the addition of sodium bicarbonate and $1 \mathrm{a}(8.0 \mathrm{mg})$ was isolated from the hydrolysate by flash CC with a Redi Sep-C18 cartridge (13 g, $\mathrm{MeOH}-\mathrm{H}_{2} \mathrm{O}, 60: 40$ to 80:20, v/v). An enzymatic hydrolysis of $\mathbf{1 a}(8.0 \mathrm{mg})$ was performed using the same method as $\mathbf{1}$ to give $\mathbf{1 b}(1.5 \mathrm{mg})$.

\subsection{Absolute Configurations of $\beta$-Glucose in $\mathbf{1}$}

The absolute configuration of $\beta$-glucose in $\mathbf{1}$ was determined by the previously reported method [21]. Pyridine $(500 \mu \mathrm{L})$ and L-cysteine methyl ester hydrochloride $(1.2 \mathrm{mg})$ were added in the hydrolysate and the mixture was heated at $60^{\circ} \mathrm{C}$ for $1 \mathrm{~h}$. $\sigma$-Tolyl isothiocyanate $(100 \mu \mathrm{L})$ was added in the mixture and heated again at $60{ }^{\circ} \mathrm{C}$ for 1 hour. The reaction was analyzed directly by HPLC with a gradient system $(10-50 \%$ of B, A: $0.1 \%(v / v)$ formic acid in water, B: $0.1 \%(v / v)$ formic acid in acetonitrile). The reaction mixture of $\mathbf{1}$ was detected at $27.4 \mathrm{~min}$. At the same HPLC conditions, authentic L- and D-glucoses were detected at 26.8 and $27.4 \mathrm{~min}$, respectively. Therefore, the absolute configuration of $\beta$-glucose in $\mathbf{1}$ was established as the $\mathrm{D}$ configuration.

\subsection{Computational Methods}

The 3D models of compounds $\mathbf{1 b}$ and $\mathbf{5}$ were built by using Chem3D modeling. Conformational structure analysis, optimizations, and ECD calculations were performed as described previously [22,23].

\subsection{Measurement of Cell Viability and NO Production}

Cell viability and nitrite levels were measured using MTT and Griess reaction assays, respectively [24].

\subsection{Measurement of $P G E_{2}$}

$\mathrm{PGE}_{2}$ levels in cell culture mediums were determined using EIA kits (R\&D Systems, MN) as reported in the previous paper [24].

\section{Conclusions}

Four new eudesmene-type sesquiterpenoids $(\mathbf{1}, \mathbf{3}, \mathbf{6}$, and $\mathbf{7})$ were obtained from a $95 \% \mathrm{EtOH}$ extract of the leaves of Aster koraiensis by repeated chromatography, along with five known compounds (2, 4, 5, 8, and 9). The chemical structures of the four new compounds and absolute configurations of the known compounds 2, 4, and 5 were established by their spectroscopic data (HR-MS, 1D- \& 2D-NMR, and ECD) measurement and by acidic and enzymatic hydrolysis. Among the isolates, the new compound 7 exhibited weak inhibitory activities on both $\mathrm{NO}$ and $\mathrm{PGE}_{2}$ production. The compounds found in this study do not appear to contribute to the anti-inflammatory activity of the extract from which they were isolated. Thus, compounds with higher activity in the leaves of $A$. koraiensis needs to be identified through further studies.

Supplementary Materials: The following are available online at http://www.mdpi.com/2223-7747/9/12/1811/s1, General Experimental Procedure, The HR-ESI-MS, ${ }^{1} \mathrm{H}-\mathrm{NMR}\left(500 \mathrm{MHz}, \mathrm{C}_{5} \mathrm{D}_{5} \mathrm{~N}\right),{ }^{13} \mathrm{C}-\mathrm{NMR}\left(125 \mathrm{MHz}, \mathrm{C}_{5} \mathrm{D}_{5} \mathrm{~N}\right)$, HSQC, COSY, HMBC, and NOESY spectra of 1 (Figures S1 S8), The HR-ESI-MS, ${ }^{1} \mathrm{H}-\mathrm{NMR}\left(500 \mathrm{MHz}, \mathrm{C}_{5} \mathrm{D}_{5} \mathrm{~N}\right.$ ), ${ }^{13} \mathrm{C}-\mathrm{NMR}\left(125 \mathrm{MHz}, \mathrm{C}_{5} \mathrm{D}_{5} \mathrm{~N}\right), \mathrm{HSQC}, \mathrm{COSY}, \mathrm{HMBC}$, and NOESY spectra of 3 (Figures S9 S15), The HR-ESI-MS, ${ }^{1} \mathrm{H}-\mathrm{NMR}\left(500 \mathrm{MHz}, \mathrm{CD}_{3} \mathrm{OD}\right),{ }^{13} \mathrm{C}-\mathrm{NMR}\left(125 \mathrm{MHz}, \mathrm{CD}_{3} \mathrm{OD}\right), \mathrm{HSQC}, \mathrm{COSY}, \mathrm{HMBC}$, and NOESY spectra of 6 (Figures S16 S21), The HR-ESI-MS, ${ }^{1} \mathrm{H}-\mathrm{NMR}\left(500 \mathrm{MHz}, \mathrm{CD}_{3} \mathrm{OD}\right),{ }^{13} \mathrm{C}-\mathrm{NMR}\left(125 \mathrm{MHz}, \mathrm{CD}_{3} \mathrm{OD}\right), \mathrm{COSY}, \mathrm{HMBC}$, and NOESY spectra of 7 (Figures S22 S27).

Author Contributions: Conceptualization, D.S.J.; Funding acquisition, D.S.J.; Investigation, J.-Y.K., Y.H.S., I.-H.L. and H.Y.C.; Project administration, H.C.K.; Resources, H.C.K.; Supervision, J.-H.C., J.L. and D.S.J.; Writing-original draft, J.-Y.K. and Y.H.S.; Writing-review \& editing, J.L. and D.S.J. All authors have read and agreed to the published version of the manuscript. 
Funding: This research was supported by a grant (grant number: NRF-2019R1A2C1083945) from the National Research Foundation of Korea (NRF) funded by the Ministry of Science and ICT (MSIT), Korea and by the Korea Institute of Science \& Technology (KIST) Institutional Program (Project No. 2E30650-20-154). This research was also supported by the project entitled "Development of Sustainable Application for Standard Herbal Resources" (grant number: KSN2012320) from the Korea Institute of Oriental Medicine.

Conflicts of Interest: The authors declare no conflict of interest.

\section{References}

1. Ahn, D.K. Illustrated Book of Korean Medicinal Herbs; Kyo-hak Publishing Co.: Seoul, Korea, 1998; p. 107.

2. Kwon, J.H.; Kang, S.W.; Shen, S.S.; Park, C.S. Occurrence of stem rot of wild Aster (Aster koraiensis) caused by Sclerotium rolfsii in Korea. Mycobiology 2001, 29, 58-60. [CrossRef]

3. Jung, H.J.; Min, B.S.; Park, J.Y.; Kim, Y.H.; Lee, H.K.; Bae, K.H. Gymnasterkoreaynes A-F, Cytotoxic polyacetylenes from Gymnaster koraiensis. J. Nat. Prod. 2002, 65, 897-901. [CrossRef] [PubMed]

4. Lee, I.K.; Kim, K.H.; Ryu, S.Y.; Choi, S.U.; Lee, K.R. Phytochemical constituents from the flowers of Gymnaster koraiensis and their cytotoxic activities in vitro. Bull. Korean Chem. Soc. 2010, 31, 227-229. [CrossRef]

5. Lee, T.G.; Hyun, S.W.; Lee, I.S.; Park, B.K.; Kim, J.S.; Kim, C.S. Antioxidant and $\alpha$-glucosidase inhibitory activities of the extracts of Aster koraiensis leaves. Korean J. Med. Crop Sci. 2018, 26, 382-390.

6. Kim, K.A.; Kang, K.D.; Lee, E.H.; Nho, C.W.; Jung, S.H. Edible wild vegetable, Gymnaster koraiensis protects retinal ganglion cells against oxidative stress. Food Chem. Toxicol. 2011, 49, 2131-2143. [CrossRef]

7. Lee, J.Y.; Song, D.G.; Lee, E.H.; Jung, S.H.; Nho, C.W.; Cha, K.H.; Pan, C.H. Inhibitory effects of 3, 5-O-dicaffeoyl-epi-quinic acid from Gymnaster koraiensis on AKR1B10. J. Korean Soc. Appl. Biol. Chem. 2009, 52, 731-734. [CrossRef]

8. Sohn, E.; Kim, J.; Kim, C.S.; Kim, Y.S.; Jang, D.S.; Kim, J.S. Extract of the aerial parts of Aster koraiensis reduced development of diabetic nephropathy via anti-apoptosis of podocytes in streptozotocin-induced diabetic rats. Biochem. Biophys. Res. Commun. 2010, 391, 733-738. [CrossRef]

9. Kim, J.; Jo, K.; Lee, I.S.; Kim, C.S.; Kim, J.S. The extract of Aster koraiensis prevents retinal pericyte apoptosis in diabetic rats and its active compound, Chlorogenic acid inhibits AGE formation and AGE/RAGE interaction. Nutrients 2016, 8, 585. [CrossRef]

10. Lee, S.B.; Kang, K.; Oidovsambuu, S.; Jho, E.H.; Yun, J.H.; Yoo, J.H.; Nho, C.W. A polyacetylene from Gymnaster koraiensis exerts hepatoprotective effects in vivo and in vitro. Food. Chem. Toxicol. 2010, 48, 3035-3041. [CrossRef]

11. Dat, N.T.; Cai, X.F.; Shen, Q.; Im, S.L.; Lee, E.J.; Park, Y.K.; Kim, Y.H. Gymnasterkoreayne G, a new inhibitory polyacetylene against NFAT transcription factor from Gymnaster koraiensis. Chem. Pharm. Bull. 2005, 53, 1194-1196. [CrossRef]

12. Jung, H.J.; Hung, T.M.; Na, M.K.; Min, B.S.; Kwon, B.M.; Bae, K.H. ACAT Inhibition of polyactylenes from Gymnaster koraiensis. Nat. Prod. Sci. 2009, 15, 110-113.

13. Butler, S.M.; Wallig, M.A.; Nho, C.W.; Pan, C.H.; Lee, E.H.; Jung, S.H.; Jeffery, E.H. A polyacetylene-rich extract from Gymnaster koraiensis strongly inhibits colitis-associated colon cancer in mice. Food. Chem. Toxicol. 2013, 53, 235-239. [CrossRef] [PubMed]

14. Park, J.Y.; Min, B.S.; Jung, H.J.; Kim, Y.H.; Lee, H.K.; Bae, K.H. Polyacetylene glycosides from Gymnaster koraiensis. Chem. Pharm. Bull. 2002, 50, 685-687. [CrossRef] [PubMed]

15. Lee, I.K.; Kim, K.H.; Ryu, S.Y.; Lee, K.R. Two new sesquiterpene glucosides from Gymnaster koraiensis. Heterocycles 2009, 8, 2827-2835. [CrossRef]

16. Lee, J.; Lee, Y.M.; Lee, B.W.; Kim, J.H.; Kim, J.S. Chemical constituents from the aerial parts of Aster koraiensis with protein glycation and aldose reductase inhibitory activities. J. Nat. Prod. 2012, 75, 267-270. [CrossRef] [PubMed]

17. Nhoek, P.; Ahn, J.; Chae, H.S.; Pel, P.; Kim, Y.M.; Lee, S.E.; Lee, J.H.; Kim, J.; Choi, Y.H.; Lee, K.; et al. Isolation of polyacetylenes with proprotein convertase/kexin type 9 downregulating activity and two new sesquiterpenes from the aerial parts of Aster koraiensis. Tetrahedron Lett. 2020, 151957. [CrossRef]

18. Kwon, J.; Ko, K.; Zhang, L.; Zhao, D.; Yang, H.O.; Kwon, H.C. An autophagy inducing triterpene saponin derived from Aster koraiensis. Molecules 2019, 24, 4489. [CrossRef]

19. Dat, N.T.; Van Kiem, P.; Cai, X.F.; Shen, Q.; Bae, K.; Kim, Y.H. Gymnastone, a new benzofuran derivative from Gymnaster koraiensis. Arch. Pharm. Res. 2004, 27, 1106-1108. [CrossRef] 
20. Wu, Q.Z.; Zhao, D.X.; Xiang, J.; Zhang, M.; Zhang, C.F.; Xu, X.H. Antitussive, expectorant, and anti-inflammatory activities of four caffeoylquinic acids isolated from Tussilago farfara. Pharm. Biol. 2016, 54, 1117-1124. [CrossRef]

21. Tanaka, T.; Tatsuya, N.; Toshihisa, U.; Kenji, T.; Isao, K. Facile discrimination of aldose enantiomers by reversed-phase HPLC. Chem. Pharm. Bull. 2007, 55, 899-901. [CrossRef]

22. Kwon, J.; Lee, H.; Ko, W.; Kim, D.C.; Kim, K.W.; Kwon, H.C.; Guo, Y.; Sohn, J.H.; Yim, J.H.; Kim, Y.C. Chemical constituents isolated from Antarctic marine-derived Aspergillus sp. SF-5976 and their anti-inflammatory effects in LPS-stimulated RAW 264.7 and BV2 cells. Tetrahedron 2017, 73, 3905-3912. [CrossRef]

23. Lee, J.S.; Jeong, M.; Park, S.; Ryu, S.M.; Lee, J.; Song, Z.; Guo, Y.; Choi, J.H.; Lee, D.; Jang, D.S. Chemical constituents of the leaves of butterbur (Petasites japonicus) and their anti-inflammatory effects. Biomolecules 2019, 9, 806. [CrossRef] [PubMed]

24. Shin, J.S.; Lee, K.G.; Lee, H.H.; Lee, H.J.; An, H.J.; Nam, J.H.; Jang, D.S.; Lee, K.T. $\alpha$-Solanine isolated from Solanum tuberosum, L. cv Jayoung abrogates LPS-induced inflammatory responses via NF- $\mathrm{KB}$ inactivation in RAW 264.7 macrophages and endotoxin-induced shock model in mice. J. Cell. Biochem. 2016, 117, 2327-2339. [CrossRef] [PubMed]

Publisher's Note: MDPI stays neutral with regard to jurisdictional claims in published maps and institutional affiliations.

(C) 2020 by the authors. Licensee MDPI, Basel, Switzerland. This article is an open access article distributed under the terms and conditions of the Creative Commons Attribution (CC BY) license (http://creativecommons.org/licenses/by/4.0/). 